
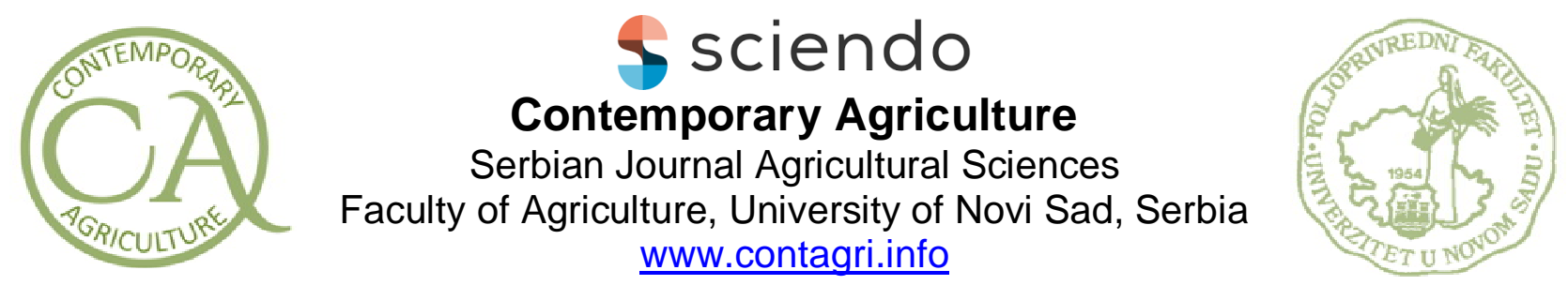

Original scientific paper

UDC: 613.287 .5

DOI: $10.2478 /$ contagri-2019-0014

\title{
RELATIONSHIP BETWEEN MILK UREA LEVEL AND MILK PARAMETERS IN THE SAANEN DAIRY GOAT
}

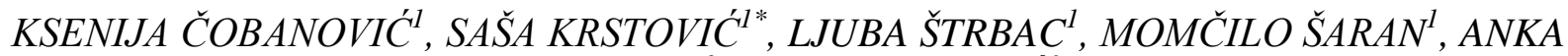 \\ KASALICA ${ }^{2}$, MILKA POPOVIĆ \\ ${ }^{1}$ Faculty of Agriculture, University of Novi Sad, Trg Dositeja Obradovića 8, 21000 Novi Sad, Serbia \\ ${ }^{2}$ JPS Dairy Institute, Autoput za Zagreb 3, 11000 Belgrade, Serbia \\ ${ }^{3}$ Faculty of Medicine, University of Novi Sad, Hajduk Veljkova 3, 21000 Novi Sad, Serbia \\ "Corresponding author: sasa.krstovic@stocarstvo.edu.rs
}

\begin{abstract}
SUMMARY
The aim of this study was to determine the urea level in Saanen goat milk and examine the relationship between milk urea (MU) level and daily milk yield (DMY), milk fat, protein, lactose and solids non-fat (SNF) percentage in dairy goats. The observation was made on 1492 samples of milk control of Saanen goats in the period from March to November 2019. The samples were categorized into four groups based on MU level: I Group 10-20 mg/dl, II group 20.01-30.00 mg/dl, III group 30.01-40.00 mg/dl, IV group >40.01mg/dl. Analyses of raw milk samples were carried out on the FOSS instruments MilcoScan in Laboratory for Milk Quality Control, at the Faculty of Agriculture, Department of Animal Science. Descriptive statistic was done using program Statistica 13.5. The goats on the observed farm were reared in a closed system with balanced diet throughout the whole year. The study showed statistically highly significant differences $(P<0.01)$ among $M U$ groups for all milk parameters. The $M U$ concentration was positively correlated $(P<0.01)$ with fat (\%), protein (\%), lactose (\%) and SNF (\%), while it was negatively correlated only with DMY $(\mathrm{kg})$.
\end{abstract}

Key words: milk urea, goat milk, milk parameters

\section{INTRODUCTION}

Variability in goat milk production is caused by rearing conditions, espacially by nutrition. Due to its biological and energy value, goat milk has an advantage in relation to cow milk (Spruzs \& Selegovska, 2004; Brito et al., 2011). According to a previous study (Park \& Haenlein, 2010), the average goat milk composition is the following: milk fat $3.8 \%$, proteins $3.5 \%$ and lactose $4.1 \%$. The fat content can vary from $2.4 \%$ to $7.8 \%$, which is the component that varies the most (Park \& Haenlei, 2010). Goat milk quality depends on many factors, including: goat breed, age, health condition, body weight, lactation length, order of lactation, lactation stadium, length of the dry period, number of daily milking, workers who perform milking, hygiene, kidding, gestation, system of production, diet, accommodation, weather conditions etc. (Park \& Haenlein, 2010; Goetsch et al. 2011; Abbas et al. 2014; Krajinović \& Pihler, 2014).

Urea, as a part of the non-protein fraction of nitrogen in milk, represents the final product of protein metabolism in the rumen of ruminants. Toxic ammonia comes into the liver by portal bloodstream and undergoes there the transformation to urea, which is then transferred into milk. Thus, urea content can be determined both in the bloodstream and in milk (Rajala-Schultz \& Saville, 2003). When milk samples are taken as part of regular Dairy 
Herd Improvement (DHI) testing, sampling for MU testing involves no extra labor, and it is cheaper than sampling and analyzing blood. Nutrition and content of crude proteins in the diet have the greatest influence on milk urea content (Godden et al., 2001). Milk urea concentration is a useful indicator of energy and protein balanced diet and it is used in systematic control of cow milk, while in sheep and goat milk it is not determined or controlled. Apart from feeding, milk urea content can be affected by some other factors such as season (Godden et al., 2001; Hojman et al., 2005; Fatehi et al., 2012), milk yield (Godden et al., 2001; Hojman et al., 2005), stage of lactation (Moore \& Varga, 1996; Godden et al, 2001; Rajala-Schultz \& Saville, 2003; Fatehi et al., 2012), parity (Godden et al., 2001; Hojman et al., 2005), breed (Wattiaux et al., 2005), body weight (Hojman et al., 2005), etc.

Main determinants of urea formation in milk are the amount of crude protein (CP) and the ratio of protein and energy portion in diet. Goat diet with excessive amount of crude protein and energy-unbalanced diet cause the excess of nitrogenous substance in rumen, along with release of ammonia and rise of urea blood and milk levels.

The physiological concentration of MU in goat milk has not been defined, unlike cow milk in which it ranges from 15 to $30 \mathrm{mg} / \mathrm{dl}$. It is also necessary to determine MU for goat milk. Some authors reported different MU levels for goat milk. Brun-Bellut et al. (1991) reported the optimum MU range of $28-32 \mathrm{mg} / \mathrm{dl}$. Min et al. (2005) found MU levels between 17.6 and $21.6 \mathrm{mg} / \mathrm{dl}$. Laudadio \& Tufareli (2010) reported MU level between 21.7 and $23.1 \mathrm{mg} / \mathrm{dl}$, while Rapetti et al. (2014) found $34.2 \mathrm{mg} / \mathrm{dl}$.

Therefore, the aim of this research was to determine the urea level in Saanen goat milk and examine the relationship between milk urea level and daily milk yield, milk fat, protein, lactose and solids non-fat percentage.

\section{MATERIAL AND METHODS}

Milk samples were collected from a single commercial flock of Saanen goats in the period from March to October 2019. All samples were taken once a day, during the normal milking time. Milk recording control was performed by AT4 method (ICAR, 2019). There were no changes in the feeding regime throughout the lactation period and the goats on the farm were in a closed system with balanced diet throughout the whole year.

Milk urea and chemical composition were determined by the infrared test method (ISO 9622:2013) by MilcoScan FT in the Laboratory for Milk Quality Control, at the Faculty of Agriculture in Novi Sad. The Laboratory is accredited in accordance with the international standard, ISO 17025:2017 and ICAR guidelines (2014). The complete dataset consisted of 1491 samples of milk control of Saanen goats, which included date of test (season), daily milk yield, milk fat, protein, lactose and solids non-fat content, as well as MU level.

The average values and variability of the examined traits, as well as the effect of the factors on these traits were studied by means of the PROC UNIVARIATE and PROC GLM procedures within the Statistica software package (ver. 13.5 StatSoft Company). Post-hoc analysis (Duncan test) was used to determine statistically significant differences between the mean values of different MU groups, with significance levels of $\mathrm{P}<0.05$ and $\mathrm{P}<0.01$.

Finally, the analysis of correlation between MU concentration and production variables was performed using the correlation procedure. Model effects were declared significant at $\mathrm{P}<0.05$ and $\mathrm{P}<0.01$ for all parameters.

\section{RESULTS AND DISCUSSION}

The average results for milk urea concentration (MU), milk fat, total protein, lactose and solids non-fat (SNF) percentages and daily milk yield (DMY) are presented in Table 1.

\begin{tabular}{ccccccc}
\multicolumn{6}{c}{ Table 1. Means, standard deviations (SD) and coefficient of variation (CV) of analyzed variables } \\
\hline Trait & N & Mean & Min & Max & SD & CV (\%) \\
\hline MU (mg/d) & 1491 & 29.94 & 10.40 & 59.70 & 7.33 & 24.52 \\
Fat (\%) & 1491 & 3.07 & 1.49 & 5.79 & 0.72 & 23.40 \\
Protein (\%) & 1491 & 2.76 & 1.88 & 4.70 & 0.35 & 12.77 \\
Lactose (\%) & 1491 & 4.13 & 3.45 & 4.81 & 0.21 & 5.12 \\
SNF (\%) & 1491 & 10.87 & 8.71 & 15.13 & 1.03 & 9.51 \\
DMY (kg) & 1491 & 2.54 & 0.60 & 6.40 & 0.99 & 39.08 \\
\hline
\end{tabular}

The mean MU concentration was $29.94 \mathrm{mg} / \mathrm{dl}$, which is within the optimal values for dairy goats in the range of 28$32 \mathrm{mg} / \mathrm{dl}$ (Brun-Bellut et al., 1991).

The mean values for milk fat and protein determined in this study were lower than the average values for goat milk reported by Park \& Haenlein (2010), while lactose was at the same level. 
We categorized samples into four groups based on MU values. In this way, the samples with the highest MU level (> $40 \mathrm{mg} / \mathrm{dl}$ ) had the highest content of fat, protein, lactose and SNF, but the lowest DMY (kg) (Table 2).

Table 2. Effect of MU group on milk parameters

\begin{tabular}{ccccc}
\hline Trait & \multicolumn{5}{c}{ MU group } \\
\cline { 2 - 5 } & 1 & 2 & 3 & 4 \\
\hline Fat (\%) & $2,64^{\mathrm{a}}$ & $2.89^{\mathrm{b}}$ & $3.28^{\mathrm{c}}$ & $3.37^{\mathrm{c}}$ \\
Protein (\%) & $2.57^{\mathrm{a}}$ & $2.65^{\mathrm{b}}$ & $2.85^{\mathrm{c}}$ & $3.07^{\mathrm{d}}$ \\
Lactose (\%) & $4.08^{\mathrm{a}}$ & $4.12^{\mathrm{b}}$ & $4.16^{\mathrm{bc}}$ & $4.17^{\mathrm{c}}$ \\
SNF (\%) & $10.20^{\mathrm{a}}$ & $10.57^{\mathrm{b}}$ & $11.19^{\mathrm{c}}$ & $11.46^{\mathrm{d}}$ \\
DMY (kg) & $3.13^{\mathrm{a}}$ & $2.54^{\mathrm{b}}$ & $2.50^{\mathrm{c}}$ & $2.23^{\mathrm{d}}$ \\
\hline Means within the same & row with different & superscripts $\left(^{\mathrm{a}, \mathrm{b}, \mathrm{c}, \mathrm{d}}\right)$ differ & significantly \\
$(\mathrm{P}<0.01)$ & & &
\end{tabular}

By comparing these parameters, it can be noted that there were statistically highly significant differences among MU groups for each milk parameter.

The coefficient of correlation between MU and other analysed milk parameters is presented in Table 3 .

Table 3. Coefficient of correlation between MU and milk components and daily milk yield

\begin{tabular}{cccccc}
\hline Trait & $\begin{array}{c}\text { Fat } \\
(\mathbf{\%})\end{array}$ & $\begin{array}{c}\text { Protein } \\
(\mathbf{\%})\end{array}$ & $\begin{array}{c}\text { Lactose } \\
(\mathbf{\%})\end{array}$ & $\begin{array}{c}\text { SNF } \\
(\boldsymbol{\%})\end{array}$ & $\begin{array}{c}\text { DMY } \\
(\mathbf{k g})\end{array}$ \\
\hline MU (mg/dl) & $0.3407 * *$ & $0.4304 * *$ & $0.1089 * *$ & $0.3888 * *$ & $-0.1762 * *$ \\
\hline \multicolumn{7}{l}{ Significant differences: $* \mathrm{P}<0.05 ; * * \mathrm{P}<0.01 ;$ NS: Non-Significant } \\
\hline
\end{tabular}

Table 3 indicates that MU concentration was positively correlated $(\mathrm{P}<0.01)$ with fat, protein, lactose and SNF, and negatively correlated only with DMY. Bendelja-Ljoljić (2018) found in Alpina goat milk a positive coefficient of correlation between MU concentration and daily milk yield and protein content. In case of all other milk components, the correlation coefficient was negative.

Bendelja et al. (2011) reported a positive correlation between milk fat content and MUN in cow milk. Negative correlation between protein content and milk urea concentration in milk was determined by Abdouli et al. (2008), while Rajala-Schultz and Saville (2003) reported no significant association. Bendelja et al. (2011) found a positive coefficient of correlation between MU and protein. Hojman et al. (2005) explained that higher content of neutral detergent fibres in forage may increase milk fat content and at the same time cause increased urea concentration, due to high degradability of its proteins.

\section{CONCLUSION}

The results of this study indicate that there are positive and statistically significant correlations between milk urea concentration and milk fat, protein, lactose and solids non-fat content.

Increasing MU levels appears to be negatively associated with daily milk yield.

Maintaining and monitoring MU in dairy goat herds provide an opportunity to formulate the dietary protein constituency that optimizes nitrogen utilization for milk production.

Acknowledgments: This research is a part of project financially supported by Ministry of Education, Science and Technological Development, Republic of Serbia (project: "Production of hard cheese with added value of milk produced in organic and selfsustaining systems", no. TR31095).

\section{REFERENCES}

Abbas H.M., Hassan F.A., El-Gawadm A.A., Enbak K. (2014): Physicochemical Characteristics of Goat's Milk. Life Science Journal, 11: 1s.

Abdouli H., Rekik B., Haddad-Boubaker A. (2008): Non-nutritional factors associated with milk urea concentrations under Mediterranean conditions. World Journal of Agricultural Sciences, 4(2): 183-188.

Allen M.O., Oftedal O.T., Baer D.J. (1996): The feeding and nutrition of carnivores; in wild mammals in captivity. Kleiman DG (ed), University of Chicago Press, Chicago, Illinois, 139-147.

Bendelja D., Prpić Z., Mikulec N., Ivkić Z., Havranek J., Antunac N. (2011): Milk urea concentration in Holstein and Simmental cows. Mljekarstvo, 61(1): 45-55. 
Bendelja-Ljljoljić D. (2018): Milk urea concentration as an indicator of optimal nutrition and quality of goat milk. PhD Thesis, University of Zagreb, Faculty of Agriculture.

Brito L.F., Silva F.G., Melo A.L.P., Caetano G.C., Torres R.A., Rodrigues M.T., Menezes G.R.O. (2011): Genetic and environmental factors that influence production and quality of milk of Alpine and Saanen goats. Genetics and Molecular Research, 10: 3794-3802.

Brun-Bellut J., Lindberg J.E., Hajipanayotou M. (1991): Protein nutrition and requirements of adult dairy goats. In: MorandFeher, P. (ed.), Gat Nutrition. Pudoc, Wageningen, pp. 82-93.

Fatehi F., Zali A., Honarvar M., Dehghan-Banadaky M., Young A.J., Ghiasvand M., Efekhari M. (2012): Review of the relationship between milk urea nitrogen and days in milk, parity, and monthly temperature mean in Iranian Holstein cows. Journal of Dairy Science, 95(9): 5156-5163.

Godden S.M., Kelton D.F., Lissemore K.D., Walton J.S., Leslie K.E., Lumsden J.H. (2001): Milk urea testing as a tool to monitor reproductive performance in Ontario dairy herds. Journal of Dairy Science, 84(1): 1397-1426.

Goetscha A.L., Zeng S.S., Gipson T.A. (2011): Factors affecting goat milk production and quality. Small Ruminant Research, 101(1): 55-63.

Hojman D., Gips M., Ezra E. (2005): Association between live body weight and milk urea concentration in Holstein cows. Journal of Dairy Science, 88(2): 580-584.

Krajinović M. \& Pihler I. (2014): Tehnologija kozarske proizvodnje. Univezitet u Novom Sadu, Poljoprivredni fakultet, $163-211$.

Laudadio V. \& Tufarelli V. (2010): Effects of palleted total mixed rations with different rumen degradable protein on milk yield and composition of Jonica dairy goat. Small Ruminant Research, 90: 47-52.

Min B.R., Hart S.P., Sahlu T., Satter L.D. (2005): The effect of diets on milk production and composition, and on lactation curves in pastured dairy goats. Journal of Dairy Science, 88: 2604-2615.

Moore D.A. \& Varga G. (1996): BUN and MUN: urea nitrogen testing in dairy cattle. Comped. Cont. Educ. Pract. Vet., 18(12): $712-720$.

Park Y.W. \& Haenlein G.F.W. (2010): Milk production. Goat Science and Production, 12(4): 275-292.

Rajala-Schultz P.J. \& Saville, W.J.A. (2003): Sources of variation in milk urea nitrogen in Ohio dairy herds. Journal of Dairy Science, 86(5): 1653-1661.

Rapetti L., Colombini S., Galassi G., Crovetto G.M., Malagutti L. (2014): Relationship between milk urea level, protein feeding and urinary nitrogen excretion in high producing dairy goats. Small Ruminant Research, 121: 96-100.

Spruzs J. \& Selegovska E. (2004): Feeding of goats under conditions of organic farming. Veterinarija in zootechnika, 27(49): 101-105.

Wattiaux M.A., Nordheim E.V., Crump P. (2005): Statistical Evaluation of factors and interactions affecting dairy herd improvement milk urea nitrogen in commercial Midwest dairy herds. Journal of Dairy Science, 88(8): 3020-3035.

Received: 7.11.2019.

Accepted: 14.11.2019. 